anales de psicología / annals of psychology

2021, vol. 37, $\mathrm{n}^{\circ} 1$ (january), 88-100

https://doi.org/10.6018/analesps.422381
(C) Copyright 2021: Editum. Servicio de Publicaciones de la Universidad de Murcia. Murcia (Spain) ISSN print edition: 0212-9728. ISSN online edition (http://revistas.um.es/analesps): 1695-2294. Online edition License Creative Commons 4.0: BY-SA

\title{
Research orientations related to guidance and counselling programmes: A content analysis study
}

\author{
Hüseyin Uzunboylu*, and Serdar Özmen
}

Near East University. Nicosia, Mersin (Turkey).

\begin{abstract}
Título: Orientaciones de investigación relacionadas con los programas de orientación y asesoramiento: un estudio de análisis de contenido.

Resumen: Los servicios de orientación y asesoramiento psicológico, que se consideran parte integrante del sistema educativo, se refieren al conjunto de servicios sistemáticos que se ofrecen de acuerdo con un determinado plan y programa. Los programas de orientación y asesoramiento (POA) son de considerable importancia en la prestación de estos servicios basados en datos y pruebas y en la obtención de la eficiencia esperada de los servicios. El objetivo de este estudio es evaluar los estudios sobre POA en términos de análisis de contenido, revelar la situación actual y determinar las orientaciones de investigación científica relacionadas con estos estudios. Con este estudio, se pretendía que el personal de campo, los educadores y los investigadores reconocieran los desajustes en el campo de POA, obtengan diferentes perspectivas sobre sus campos de estudio y arrojen luz sobre nuevas investigaciones en este campo. Los datos relacionados con este estudio, que fue diseñado según el modelo de encuesta descriptiva utilizando metodología de investigación cualitativa, se obtuvieron mediante el método de revisión de documentos. En relación con el tema de investigación, se examinaron 105 estudios de tesis de posgrado en la base de datos de tesis y disertaciones de ProQuest entre 2007 y 2019, y 133 artículos de revistas en la base de datos de Web of Science. Los datos obtenidos se evaluaron mediante el método de análisis de contenido descriptivo. Los estudios sobre el tema han aumentado en los últimos años y más de la mitad de las investigaciones se han realizado en Estados Unidos. Se observó que los estudios experimentales se realizaron utilizando la metodología de investigación más cuantitativa, que se puso más énfasis en el proceso de evaluación del programa y que se estudiaron grupos de muestra de diferentes niveles, especialmente orientadores escolares. Además, hay algunos hallazgos que respaldan que hay más estudios sobre programas de intervención y prevención basados en la comunidad que estudios basados en la escuela, y también respaldan el hecho de que las investigaciones relacionadas con la escuela están prestando especial atención a investigar los efectos, las percepciones y experiencias, el diseño y la evaluación del programa. Finalmente, se interpretaron los resultados de los hallazgos de la investigación y se presentaron las recomendaciones para los investigadores.

Palabras clave: Programas de orientación. Programas de asesoramiento. Programas integrales de orientación y asesoramiento. Plan de estudios de orientación. Programas de orientación de clase. Análisis de contenido.
\end{abstract}

\section{Introduction}

Some of the developments in the world can be listed as follows; Information technologies (Stosic et al., 2020), business and economics developments (Ahmed et al., 2020), new threats (for example COVIT-19) emerging in the fields of health (Ozcinar, 2020), inequalities in education systems between countries (Park, 2020), orientation towards distance education in the field of education and training (Garbin \& others, 2020), multicultural education and training programs

* Correspondence address [Dirección para correspondencia]:

Hüseyin Uzunboylu, Near East University, Higher Education Planning, Supervision, Accreditation and Coordination Board, Nicosia, Mersin 10 (Turkey).E-mail: huseyin.uzunboylu@gmail.com

(Article received: 09-04-2020; revised: 06-05-2020; accepted: 17-06-2020)
Abstract: Guidance and psychological counselling services, which are seen as an integral part of the education system, refer to the whole of systematic services offered in line with a certain plan and programme. Guidance and counselling programmes (G\&CP) are of considerable importance in the provision of these services based on data and evidence and in obtaining the expected efficiency from the services. The aim of this study is to evaluate the studies on G\&CP in terms of content analysis, to reveal the current situation and to determine the scientific research orientations related to these studies. With this study, it was aimed that field staff, educators and researchers should recognise the gaps in the G\&CP field, gain different perspectives on their fields of study and shed light on new research in this field. The data related to this study, which was designed according to the descriptive survey model using qualitative research methodology, were obtained by document review method. In connection with the topic of research, 105 graduate thesis studies in the ProQuest Dissertations and Theses database between 2007 and 2019 and 133 journal articles in the Web of Science database were examined. The obtained data were evaluated using the descriptive content analysis method. Studies on the subject have increased in recent years and more than half of the research has been carried out in the United States. It was observed that experimental studies were conducted using the most quantitative research methodology, that more emphasis was placed on the programme evaluation process and that sample groups at different levels, especially school counsellors, were studied. Additionally, there are some findings supporting that there are more studies concerning community-based preventive and intervention programmes than school-based studies, and also supporting the fact that school-related researches are especially paying attention to investigate the effects of the programme, perceptions and experiences of the programme, programme design and programme evaluation. Finally, the results from the research findings were interpreted and the recommendations for the researchers were presented.

Keywords: Guidance programmes. Counselling programmes. Comprehensive guidance and counselling programmes. Guidance curriculum. Class guidance programmes. Content analysis. gain importance (Uzunboylu \& Altay, 2019) and people need more counselling and guidance with the shrinking World (Saricam, \& Ozbey, 2019).

Guidance is the process of helping an individual to make choices by recognising himself and his environment (Shertzer \& Stone 1981), to understand himself, to set goals and to change his behaviour positively (Miller et al., 1978). Counselling services are central to guidance services (Yesilyaprak, 2019). Counselling service is a relational process that contributes individuals to make decisions, solve problems, gain self-confidence, develop a healthier life to enjoy, identify their needs and design strategies to meet their needs (Schmidt, 2008). This relationship is a professional relationship that empowers individuals, families and groups in mental health, wellness, education and career development (American Consuling Association, 2019). At the core of 
counselling is helping others (Illovsky, 2013). However, this assistance process is not a random spontaneous process. Guidance and counselling services are provided systematically and within a specific programme (Gysbers \& Henderson, 2012).

Psychological counselling and guidance services are systematic services carried out in accordance with a specific plan and programme refers to the whole (Guven, 2019). There are different approaches on how to deliver these services. According to Myrick (2011), there are four main approaches that can be identified, which include crisis, remedial, preventive and developmental approaches in the field of psychological counselling and guidance: In crisis-oriented counselling and guidance approach, it is aimed to help the individual in crisis situations, such as extraordinary events, that may occur during various periods of life and separation of parents and exposure to violence. In the remedial counselling and guidance approach, it focuses on the individual's shortcomings. Guidance and counselling interventions are applied to complement the individual's shortcomings and regulate their faulty behaviour. Preventive psychological counselling and guidance approach provides services for predicting potential problems, such as school failure, substance abuse, unemployment and taking the necessary precautions before they arise. Developmental counselling and guidance approach is a flexible approach that emphasises the individual's interests and developmental needs. The developmental approach is a holistic approach, which includes preventive, curative and crisis approaches. This approach has emerged as a response to the limitation of specific problems and the emphasis on corrective, remedy relief for problems and aims at supporting the development of the individual as a whole (Kuzgun, 2009; Myrick, 2011; Yesilyaprak, 2019). The developmental approach in guidance and counselling services aims at supporting the individual in the fields of social-emotional, academic and career development and to gain various competencies related to these fields (Thompson, 1992). This approach requires an organised planned curriculum (Myrick, 2011). Guidance and counselling services based on a developmental approach are offered within a programme. As with other educational programmes, the development process of G\&CP consists of stages of planning, design, implementation, evaluation and empowerment (Gysbers \& Henderson, 2012). G\&CP is designed, implemented and evaluated after the planning phase (Nazli, 2005). After the evaluation phase, improvement, regulation and strengthening works related to the programme are carried out (Erkan, 2017; Gysbers \& Henderson, 2012).

G\&CP can be developed for different areas of study due to the wide range of areas of expertise in the field of guidance and psychological counselling. The Council for Accreditation of Counselling and Related Educational Programmes (CACREP, 2016) defined its entry-level areas of expertise as school counselling, career counselling, clinical mental health counselling, clinical rehabilitation counselling, marriage, couple and family counselling, student affairs and college coun- selling, addictions counselling and rehabilitation counselling. Considering that guidance and counselling services operate in many areas, such as education, health, industry and social assistance (Ilgar, 2002; Schmidt, 2008), it is important to examine community-based counselling programmes along with school-based work.

In terms of accountability in guidance and counselling services, G\&CP is of great importance in providing databased and evidence-based services and obtaining desired results from these services (Erkan, 2017; Gysbers \& Henderson, 2012; Nazli, 2005). However, it is stated that the studies in this area are not sufficient (Villares \& Dimmitt, 2017; Whiston, 2007). Studies where the comprehensive developmental guidance model are analysed (Macdonald \& Sink, 1999), studies on identification of research priorities and opportunities in the field of school counselling (Villares \& Dimmitt, 2017) and studies that examine themes and trends in school counselling journals (Falco et al., 2011; VasilieneVasiliauskiene et al., 2020; Zagelbaum et al., 2014) take place in the literature very often. Additionally, studies of psychological counselling journals with content analysis method (Buboltz et al., 2010; Buboltz et al., 1999; Donald \& Ng, 2014; Oh et al., 2017), studies in the field of psychological counselling and guidance which are examined thematically and methodologically (Turk \& Cihangiroglu, 2018) and studies in which the content analysis of Counselling Association's Congress Sessions is conducted (Helwig \& Schmidt, 2011) are available. However, there is no study in the literature that examines research orientations related to G\&CP. It is thought that the work has a distinct importance in terms of filling this gap in the literature. In addition, the study of the programmes has recently attracted attention all over the world as a topic of research in its own right (Hursen et al., 2016). It is thought that identifying research orientations related to G\&CP will make important contributions to shed light on future research.

The purpose of this study is to examine the studies conducted universally on G\&CP, to reveal the existing situation and to determine scientific research directions as regards studies conducted in this field. In this study, which aims to provide an overview of G\&CP-related research orientations, basic research designs and methodological trends are tried to be determined along with general themes. In addition, with this study, it is aimed that field employees, educators and researchers recognise the gaps in the programmes and gain different perspectives on G\&CP-related studies. In this context, answers to the following questions have been sought:

1. What is the distribution of studies by years and countries?

2. What are the general themes of the works?

3. What is the distribution of studies by research methodology and method type?

4. What is the distribution of studies by the participants?

5. What is the distribution of the articles included in the study by the number of authors? 


\section{Method}

This research is a qualitative study based on a descriptive survey model, aimed at evaluating G\&CP-related studies in terms of content analysis. The descriptive survey model was preferred because it is a method (Yildirim \& Simsek, 2006) that aims to describe individuals (Karasar, 2005; Kaptan, 1998), events or current situations related to various subject areas as it is and provides generalisable results.

In this method, the publications related to the study area determined are surveyed systematically in the beginning. Publications selected within the scope of the research are coded in accordance with the determined criteria, such as research subject, research method, publication year and symbolic research outputs. Then, the encoded data are combined on a certain data set by frequency analysis. Finally, generalisable results are achieved by interpreting the obtained data (King \& He, 2005). In this study, G\&CP studies from ProQuest Dissertations and Theses and Web of Science databases between 2007 and 2019 were systematically surveyed. The data obtained from the surveyed studies were coded and analysed in accordance with the criteria determined in accordance with the research questions. In line with the results of the analysis, the current situation related to G\&CP has been described and current research trends have been tried to be determined.

\subsection{Data source and data collection}

Data related to the research were collected from two different sources in the web environment. Graduate thesis studies indexed in ProQuest Dissertations and Theses database and research articles indexed in Web of Science database constitute the data source of this study. ProQuest Dissertations and Theses Global has been favoured because it is the most comprehensive thesis database worldwide (Feeney, 2014; Morichika \& Shibayama, 2016) and because it is a digital library (Kousha \& Thelwall, 2019) that provides access to scientific reviews and theses and also indexes them. Having been operating for more than a hundred years, Web Of Science, it is one of the world's leading citation databases, containing important citation indexes, particularly from Science Citation Index Expanded, Social Sciences Citation Index and Arts and Humanities Citation Index, with over 18,000 journals and information from different disciplines (Liu, 2019). Web of Science, which has strong coverage with citation data, has been preferred because it is one of the most widely used databases in literature surveys in different scientific fields (Chadegani et al., 2013) and due to its dense contents in terms of social sciences, education and educational sciences (Karasozen et al., 2011). First, G\&CP-related ProQuest
Dissertations and Theses database and 158 graduate thesis studies were reached with the words "guidance programme, counselling programme, guidance curriculum, classroom guidance programme, classroom guidance". The Web of Science database was then scanned by using the same keywords and as a result of that searching method, 248 research articles were reached. After initial reading, evaluation and classification of the sources, 53 graduate thesis studies and 115 research articles were not evaluated due to lack of full text or not related to the subject. As a result, 105 graduate thesis studies and 133 research articles formed the data source of this research.

\subsection{Limitations of the study}

This study examined dissertations and research articles at the graduate level between 2007 and 2019. Data for the year 2019 are limited as the research is carried out in the second half of 2019. Thesis studies examined in the research are limited to postgraduate theses in the ProQuest Dissertations and Theses Global database. In addition, the research articles examined are limited to the research articles published by scientific journals indexed in the Web of Science database.

\subsection{Data analysis}

The studies included in this research were analysed using the content analysis method. According to Cohen, Manion and Morrison (2007), content analysis is the process of summarising and reporting messages and main content derived from written data. Research in content analysis has been used because of it being a method used mainly in analysing the written data (Ozdemir, 2010), in reviewing the implications of the messages provided by the text (the sword Büyüköztürk et al.,), in serving holistic perspective in order to determine research trends in the field the opportunity to look (Uzunboylu \& Gundogdu, 2018) and in signifying the variables in order to measure systematic and objective analysis of means (Ozdemir, 2010).

As a result of document review studies, the data obtained from the theses and articles determined on the subject of the study were analysed by the descriptive content analysis method, which is a type of content analysis that is frequently used in the analysis of written data. Descriptive content analysis is preferred because it is a content analysis type (Zaid, 2020; Calik \& Sozbilir, 2014; Cohen et al., 2007; Dincer, 2018) that allows to evaluate the general trends systematically and evaluate them in a descriptive dimension. Within the scope of the research, descriptive content analysis process was carried out in five stages. The stages of the descriptive content analysis process are shown in Figure 1. 


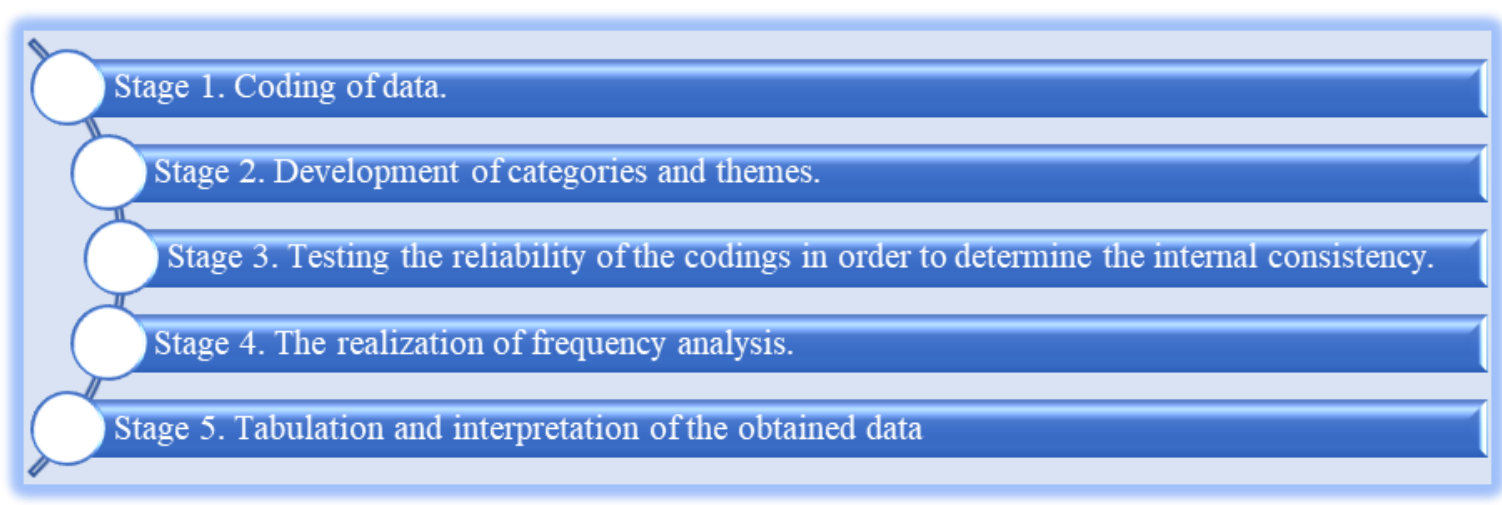

Figure 1. Descriptive content analysis process.

The descriptive content analysis process started with the determination of the codes in the beginning. The codes were determined by giving names to the meaningful sections between the data. According to Strauss and Corbin (1990), there are three types of coding formats: codings made according to previously determined concepts, codings made according to the concepts extracted from the data, and codings made within a general framework. During the coding of the research data, the codings related to the publication year of the studies and the number of authors in the articles were carried out according to the predefined concepts. The coding conducted according to the countries in which the studies were realised, the programme development process, the areas of development in guidance, study topics, research methodology, type of method, data collection tools, data analysis methods and the participants were made according to the concepts extracted from the data. During the coding of the data, a "publication classification form" was created by the researchers on the Microsoft Excel spreadsheet and the codings were carried out through this form.

The data encoded in the second stage of the data analysis process were classified and categorised. In this process, categories and themes were developed with the help of common features among the coded data. In the third stage, studies were carried out to determine the internal consistency between the codings and to carry out reliability analyses. Reliability has great importance for ensuring objectivity in content analysis studies (Lombard et al., 2004). Therefore, the Miles and Huberman's (2016) model has been used to determine intrinsic consistency in encodings and to test the reliability of encodings. For this purpose, apart from the researchers, a school counsellor and an academic from the guidance and psychological counselling field conducted a random study of 9 dissertations and 15 articles on reliability. Encoder consistency reliability coefficient was based on the data obtained. It designated 82 and obtained the result that the encodings were reliable.

Frequency analyses were carried out in the fourth phase of the data analysis process. The data obtained as a result of codings were analysed using descriptive statistical methods (percentage and frequency analysis). Accordingly, the fre- quencies of the data and the percentages based on these frequencies were calculated to correspond to the answer to each question included in the sub-objectives of the research. In the fifth stage of the data analysis process, the obtained numerical data were tabulated and interpreted.

\section{Findings}

With this research, G\&CP articles and theses made at the graduate level were evaluated for the purpose of the research. Thus, research trends related to the field were determined. In this section, the findings obtained from G\&CP studies are provided in accordance with the purpose of the research.

\subsection{Findings on the distribution of studies by publi- cation years and countries}

Within the scope of this research, findings were obtained from 105 graduate thesis studies and 133 research articles, 88 of which are doctoral and 17 of which are master's thesis. The most studies on G\&CP were conducted between 2016 and 2017. It can be stated that research in this area has increased quantitatively, especially since 2015 . The distribution of the studies by publication years is given in Table 1 .

Table 1. Distribution of studies by year of publication.

\begin{tabular}{lcc}
\hline \multicolumn{1}{c}{ Years } & $\begin{array}{c}\text { Frequency } \\
(f)\end{array}$ & $\begin{array}{c}\text { Percentage } \\
(\%)\end{array}$ \\
\hline 2007 & 11 & 4.6 \\
2008 & 8 & 3.4 \\
2009 & 16 & 6.7 \\
2010 & 15 & 6.3 \\
2011 & 18 & 7.6 \\
2012 & 26 & 10.9 \\
2013 & 17 & 7.1 \\
2014 & 15 & 6.3 \\
2015 & 26 & 10.9 \\
2016 & 28 & 11.8 \\
2017 & 28 & 11.8 \\
2018 & 22 & 9.2 \\
2019 & 8 & 3.4 \\
Total & 238 & 100 \\
\hline
\end{tabular}


When the distribution of G\&CP-related studies by countries was examined, it was found that the most studies were conducted in the USA. More than half ( $n=142,55.9 \%)$ of the world studies on G\&CP were conducted in the United States. The United States is followed by the Netherlands, Turkey, Spain and South Korea. Studies have also been carried out in European countries, such as Britain, South American countries, such as Brazil, far eastern countries, such as China and Japan, and African countries, such as South Africa, Uganda, Tanzania and Kenya. The distribution of the studies by country is given in Table 2 .

Table 2. Distribution of studies by country.

\begin{tabular}{lcc}
\hline \multicolumn{1}{c}{ Country } & $\begin{array}{c}\text { Frequency } \\
(f)\end{array}$ & $\begin{array}{c}\text { Percentage } \\
(\%)\end{array}$ \\
\hline ABD & 142 & 55.9 \\
The Netherlands & 8 & 3.1 \\
Turkey & 8 & 3.1 \\
Spain & 7 & 2.7 \\
Republic of Korea & 6 & 2.4 \\
The UK & 5 & 2 \\
Japan & 5 & 2 \\
South Africa & 5 & 2 \\
China & 4 & 1.6 \\
Brazil & 3 & 1.2 \\
Uganda & 3 & 1.2 \\
Tanzania & 3 & 1.2 \\
Republic of Kenya & 3 & 1.2 \\
Other & 52 & 20.4 \\
Total & 257 & 100 \\
\hline
\end{tabular}

\subsection{Findings on the distribution of studies by sub-} jects

The main themes related to the programme development process, guiding development areas and research topics were examined in the distribution of studies by subjects. When the G\&CP research was examined according to the programme development process, it was found that the studies were concentrated in the programme evaluation phase $(n=83$, $34.9 \%$ ). The G\&CP research includes all the phases of the programme development process, including the programme design, implementation and evaluation studies $(n=65$, $27.3 \%$ ). Table 3 presents the distribution of G\&CP studies according to the programme development process.

Table 3. Distribution of studies by programme development process.

\begin{tabular}{lcc}
\multicolumn{1}{c}{ Programme development process } & $\begin{array}{c}\text { Frequency } \\
(f)\end{array}$ & $\begin{array}{c}\text { Percentage } \\
(\%)\end{array}$ \\
\hline Programme Design & 20 & 8.4 \\
Programme Implementation & 13 & 5.4 \\
Programme Evaluation & 83 & 34.9 \\
Programme Design-Evaluation & 8 & 3.4 \\
Programme Implementation-Evaluation & 49 & 20.6 \\
Programme Design-Implementation- & 65 & \\
Evaluation & & 27.3 \\
Total & 238 & 100 \\
\hline
\end{tabular}

anales de psicología / annals of psychology, 2021, vol. $37, \mathrm{n}^{\circ} 1$ (january)
When the studies on G\&CP were examined according to development areas in guidance, it was found that most of the studies were conducted in the social-emotional development area $(n=157,66 \%)$ and least in the academic development area $(n=12,5.1 \%)$. Studies $(n=46,19.3 \%)$ involving socialemotional, academic and career development areas are also quite large. The distribution of the studies according to the development areas in guidance is given in Table 4.

Table 4. Distribution of studies by development areas in guidance.

\begin{tabular}{|c|c|c|}
\hline \multirow{2}{*}{ Development areas } & \multicolumn{2}{|c|}{ FrequencyPercentage } \\
\hline & $(f)$ & $(\%)$ \\
\hline Social-Emotional Development & 157 & 66 \\
\hline Career Development & 16 & 6.7 \\
\hline Academic Development & 12 & 5.1 \\
\hline Academic Development-Career Development & 4 & 1.7 \\
\hline $\begin{array}{l}\text { Social-Emotional Development-Academic } \\
\text { Development }\end{array}$ & 2 & 0.8 \\
\hline $\begin{array}{l}\text { Social-Emotional Development-Career De- } \\
\text { velopment }\end{array}$ & 1 & 0.4 \\
\hline $\begin{array}{l}\text { Social-Emotional Development-Academic } \\
\text { Development-Career Development }\end{array}$ & 46 & 19.3 \\
\hline Total & 238 & 100 \\
\hline
\end{tabular}

The research on G\&CP is examined according to the study subjects; the outcome has been divided into two main themes called school-based studies and community-based studies. The proportion of G\&CP-related school-based studies $(n=115,43.7 \%)$ is quite close to community-based studies $(n=123,56.3 \%)$. The majority of school-based studies $(n$ $=90,57.7 \%$ ) focuses on the effects of G\&CP. The effects of G\&CP on students' career development, increased academic achievement, social-emotional development and increased wellness levels were extensively studied. Additionally, studies examining the effects of G\&CP on the prevention of violence and risky behaviour, as well as the prevention of school abandonment and absenteeism, exist. The perception and experiences of school counsellors, school administrators, teachers and students regarding G\&CP $(n=39,25 \%)$ also play an important role in school-based studies. In the studies, mostly the school counsellors, then respectively, students, school administrators and teachers, received the opinions of the school's G\&CP. School-based studies include evaluation of G\&CP and studies on design models $(n=27$, $17.3 \%)$. These studies focus mostly on what content and how G\&CP should be designed. In addition, studies on how programmes should be evaluated and programme evaluation models are examined.

Community-based studies have been dealt with at two basic levels: preventive and interventionist programmes. The proportion of community-based preventive studies $(n=58$, $43 \%)$ is close to intervention studies $(n=77,57 \%)$. In the G\&CP preventative studies, especially the prevention of substance, tobacco, alcohol and technology dependence, the prevention of infectious diseases, such as HIV, Ebola, and obesity prevention issues, come to the fore. In addition, prevention of crime and violence and the prevention of risky 
sexual behaviour are also included in preventive studies. Rehabilitation counselling for patients and their relatives $(n=$ $43,14.8 \%$ ) is prominent in interventionist G\&CP studies. In addition, this includes mother and child nutrition, marriage and relationship counselling, family counselling, rehabilita- tion counselling for disabled people and their families, and intervention efforts for neglected and abused children. The distribution of G\&CP-related research by study subjects is given in Table 5.

Table 5. G\&CP main themes.

\begin{tabular}{|c|c|c|c|c|}
\hline \multirow{2}{*}{ Themes } & \multirow{2}{*}{ Sub-themes } & \multirow{2}{*}{ Categories } & \multicolumn{2}{|c|}{ FrequencyPercentage } \\
\hline & & & $(f)$ & $(\%)$ \\
\hline \multirow{16}{*}{ 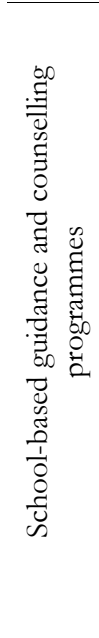 } & \multirow{8}{*}{ The effects of school G\&CP } & Impact on students' career development & 28 & 9.6 \\
\hline & & Impact on students' academic achievements & 25 & 8.6 \\
\hline & & Impact on social-emotional development of students & 23 & 7.9 \\
\hline & & Impacts on students' increased wellness levels & 7 & 2.4 \\
\hline & & Impact on prevention of violence in school & 3 & 1 \\
\hline & & Effect on prevention of risky behaviour in school & 2 & 0.7 \\
\hline & & Effect of school dropout and absenteeism prevention & 2 & 0.7 \\
\hline & & Sub total & 90 & 57.7 \\
\hline & \multirow{5}{*}{$\begin{array}{l}\text { School R\&D perceptions and experi- } \\
\text { ences }\end{array}$} & School counsellors' perception and experience with the programme & 22 & 7.6 \\
\hline & & Students' perception and experiences on the programme & 9 & 3.1 \\
\hline & & School administrators' perception and views on the programme & 4 & 1.4 \\
\hline & & Teachers' perception and views on the programme & 4 & 1.4 \\
\hline & & Sub total & 39 & 25 \\
\hline & \multirow{4}{*}{$\begin{array}{l}\text { Evaluation of school R \& DP and De- } \\
\text { sign models }\end{array}$} & School G\&CP design models & 19 & 6.5 \\
\hline & & The evaluation of school G\&CP & 8 & 2.7 \\
\hline & & Sub total & 27 & 17.3 \\
\hline Total & & & 156 & 100 \\
\hline \multirow{16}{*}{ 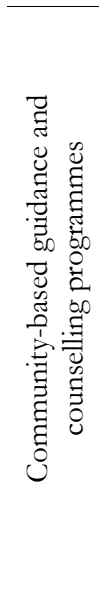 } & \multirow{7}{*}{ Preventive G\&CP } & Prevention of substance, tobacco and alcohol dependence & 18 & 6.2 \\
\hline & & Prevention of HIV, Ebola, etc. & 17 & 5.8 \\
\hline & & Prevention of obesity and nutrition counselling & 17 & 5.8 \\
\hline & & Prevention of technology addiction & 2 & 0.7 \\
\hline & & Prevention of risky sexual behaviours & 2 & 0.7 \\
\hline & & Prevention of crime and violence & 2 & 0.7 \\
\hline & & Sub total & 58 & 43 \\
\hline & \multirow{8}{*}{ Interventionist G\&CP } & Rehabilitation counselling for patients and their relatives & 43 & 14.8 \\
\hline & & Intervention programme for mother and child nutrition & 11 & 3.8 \\
\hline & & Marriage and relationship counselling & 7 & 2.4 \\
\hline & & Family counselling intervention Programme & 6 & 2.1 \\
\hline & & Rehabilitation counselling for disabled people and their families & 3 & 1 \\
\hline & & Intervention in neglected and abused children & 2 & 0.7 \\
\hline & & Other & 5 & 1.7 \\
\hline & & Sub total & 77 & 57 \\
\hline & Total & & 135 & 100 \\
\hline
\end{tabular}

\subsection{Findings on research design and method types in studies}

Effort is paid to explain the methods, data collection tools and general orientations of the data analysis processes in this section. Quantitative research methodology was used in more than half $(n=140,58.8 \%)$ of G\&CP-related research. Quantitative research is followed by qualitative research $(n=52,21.8 \%)$ and mixed method studies $(n=45$, $18.9 \%)$, respectively. Mostly, experimental methods $(n=60$, $25.2 \%$ ) were used in the research. Quantitative research methodology was used in studies where the experimental method, except for descriptive studies, cross-sectional de- scriptive field studies, correlational studies causal comparative studies and observational cohort studies are also included. Case studies $(n=21,8.8 \%)$ are mostly used for the studies using qualitative research methodology. The case study method is followed by phenomenology, meta-analysis, ethnography and exploratory research, respectively. Case studies $(n=17,7.1 \%)$ were used in mixed method research. Semiexperimental studies, simultaneous triangulation method, sequential explanatory mixed method studies and action research methods have also been used in the mixed method research. Table 6 lists the research design and distribution of G\&CP studies by type of method. 
Table 6. Distribution of studies by research methodology and method type.

\begin{tabular}{|c|c|c|c|}
\hline Research methodology & Method & $\begin{array}{c}\text { Frequency } \\
(f)\end{array}$ & $\begin{array}{c}\text { Percentage } \\
(\%)\end{array}$ \\
\hline \multirow{7}{*}{ Qualitative research } & Case study & 21 & 8.8 \\
\hline & Phenomenology & 17 & 7.1 \\
\hline & Meta-analysis & 5 & 2.1 \\
\hline & Ethnography & 4 & 1.7 \\
\hline & Exploratory research & 2 & 0.8 \\
\hline & Not specified & 3 & 1.3 \\
\hline & Sub total & 52 & 21.8 \\
\hline \multirow{8}{*}{ Quantitative research } & Experimental method & 60 & 25.2 \\
\hline & Descriptive work & 33 & 13.9 \\
\hline & Cross-sectional descriptive field study & 24 & 10.1 \\
\hline & Correlational work & 13 & 5.5 \\
\hline & Causal comparative study & 2 & 0.8 \\
\hline & Observational cohort study & 2 & 0.8 \\
\hline & Not specified & 6 & 2.5 \\
\hline & Sub total & 140 & 58.8 \\
\hline \multirow{7}{*}{ Mixed Method research } & Case study & 17 & 7.1 \\
\hline & Simultaneous triangulation & 7 & 2.9 \\
\hline & Semi-experimental Work & 7 & 2.9 \\
\hline & Sequential explanatory Hash method & 5 & 2.1 \\
\hline & Action research & 2 & 0.8 \\
\hline & Not specified & 7 & 2.9 \\
\hline & Sub total & 45 & 18.9 \\
\hline Total & & 238 & 100 \\
\hline
\end{tabular}

Surveys $(n=134,33.3 \%)$, interview forms $(n=89$, $22.1 \%)$ and scales $(n=87,21.6 \%)$ were the most used data collection tools in G\&CP. Observation forms, personal information forms, document analysis forms and checklists were also were used extensively in the studies. Inventories, success tests, video recordings evaluation forms, field notes and reflective diaries are also among the tools used in the data collection process. The distribution of data collection tools used in the studies is given in Table 7 .

Table 7. Distribution of data collection tools used in studies.

\begin{tabular}{lcc}
\multicolumn{1}{c}{ Data collection tools } & $\begin{array}{c}\text { Frequency } \\
(f)\end{array}$ & $\begin{array}{c}\text { Percentage } \\
(\%)\end{array}$ \\
\hline Survey & 134 & 33.3 \\
Interview form & 89 & 22.1 \\
Scale & 87 & 21.6 \\
Observation form & 17 & 4.2 \\
Personal information form & 15 & 3.7 \\
Document analysis form & 13 & 3.2 \\
Control list & 12 & 3 \\
Inventory & 7 & 1.7 \\
Success test & 7 & 1.7 \\
Video recordings & 6 & 1.5 \\
Evaluation form & 4 & 1 \\
Field notes & 3 & 0.8 \\
Reflective diaries & 2 & 0.5 \\
Other & 7 & 1.7 \\
Total & 403 & 100 \\
\hline
\end{tabular}

When the G\&CP research was analysed according to the distribution of data analysis methods, it was found that statistical analysis methods were mostly used $(n=390,77.1 \%)$. Mostly, descriptive statistics $(n=182,36 \%)$ were used in sta- tistical analysis methods. The $t$-test, regression analysis, chisquared test, ANOVA and correlation analysis followed the descriptive statistics method, respectively. The thematic analysis methods $(n=94,18.5 \%)$ were mostly used in the analysis of qualitative data. The methods of thematic analysis are followed by descriptive analysis, phenomenological analysis, discourse analysis, ethnographic analysis and interaction analysis, respectively. The distribution of data analysis methods used in the studies is given in Table 8 .

Table 8. Distribution of data analysis methods used in studies.

\begin{tabular}{llcc}
\hline \multicolumn{2}{c}{ Data analysis method } & Frequency & Percentage \\
& & $(f)$ & $(\%)$ \\
\hline \multirow{5}{*}{ Statistical analysis } & Descriptive statistics & 182 & 36 \\
& t-test & 47 & 9.3 \\
& Regression analysis & 42 & 8.3 \\
& Chi-squared test & 35 & 6.9 \\
& ANOVA & 24 & 4,7 \\
& Correlation analysis & 20 & 4 \\
& Wilcoxon signed rank test & 12 & 2.4 \\
& Mann-Whitney U test & 10 & 2 \\
& Other & 18 & 3.5 \\
& Sub total & 390 & 77.1 \\
& Thematic analysis & 94 & 18.5 \\
Qualitative data analysis & Descriptive analysis & 11 & 2.2 \\
& Phenomenological analysis & 6 & 1.2 \\
& Discourse analysis & 2 & 0.4 \\
& Ethnographic analysis & 2 & 0.4 \\
& Interaction analysis & 1 & 0.2 \\
Total & Sub total & 116 & 22.9 \\
& & 506 & 100 \\
\hline
\end{tabular}




\subsection{Findings regarding the distribution of the stud- ies by participants}

When the distribution of studies by participants was examined, it was found that different levels of study groups were selected. Mostly, school counsellors $(n=46,19.1 \%)$ were included in the study group. High school students, patients, parents, university students, school administrators, individuals carrying HIV virus, teachers, elementary-middle school students, nursing mothers and individuals using cigarettes followed the school counsellors, respectively. The distribution of the research by working groups is given in Table 9.

Table 9. Distribution of research by working groups.

\begin{tabular}{lcc}
\hline \multicolumn{1}{c}{ Study group } & $\begin{array}{c}\text { Frequency } \\
(f)\end{array}$ & $\begin{array}{c}\text { Percentage } \\
(\%)\end{array}$ \\
\hline School counsellors & 46 & 19.1 \\
High school students & 33 & 13.7 \\
Patients & 25 & 10.4 \\
Mothers-fathers & 14 & 5.8 \\
University students & 13 & 5.4 \\
School administrators & 12 & 5 \\
Individuals at risk of HIV virus & 12 & 5 \\
Teachers & 11 & 4.6 \\
Primary school students & 10 & 4.1 \\
Elementary school students & 8 & 3.3 \\
Breastfeeding mothers & 8 & 3.3 \\
Smokers & 6 & 2.5 \\
Others & 43 & 17.8 \\
Total & 241 & 100 \\
\hline
\end{tabular}

\subsection{Findings regarding the distribution of articles} covered by the study by number of authors

When G\&CP-related articles were examined according to the number of authors and articles, it was observed that articles with 5-9 authors $(n=53,39.8 \%)$ were mostly included. These articles are followed, respectively, by articles with two authors, articles with 10-14 authors and articles with 3-4 authors. Research shows that single-authored articles are not much preferred $(n=8,6 \%)$. The distribution of the articles according to the number of authors in the research on G\&CP is given in Table 10 .

Table 10. Distribution of articles by author numbers.

\begin{tabular}{lcc}
\hline \multicolumn{1}{c}{ Articles } & $\begin{array}{c}\text { Frequency } \\
(f)\end{array}$ & $\begin{array}{c}\text { Percentage } \\
(\%)\end{array}$ \\
\hline Single-authored articles & 8 & 6 \\
Articles with 2 authors & 21 & 15.8 \\
Articles with 3 authors & 17 & 12.8 \\
Articles with 4 authors & 10 & 7.5 \\
Articles with 5-9 authors & 53 & 39.8 \\
Articles with 10-14 authors & 20 & 15 \\
Articles with 15-19 authors & 3 & 2.3 \\
Articles with 20+ authors & 1 & 0.8 \\
Total & 133 & 100 \\
\hline
\end{tabular}

\section{Discussion and result}

In this study, which aims to examine the current situation in the field of G\&CP and to reveal the general orientations in the studies in this field, it has been concluded that the publication type of the studies within the scope of the research is mostly scientific journal articles. Research findings suggest that G\&CP-related studies have been on the rise in recent years. The reason for the low number of researches in 2019 can be explained by the fact that collection of research data began in the second half of 2019 (as of July 2019). It can be stated that interest in G\&CP-related studies has increased more in recent years, but the studies indicate a need for academic studies in this area (Villares \& Dimmitt, 2017; Whiston, 2007).

According to the findings from this study, more than half of the world studies on G\&CP were conducted in the United States. Guidance and counselling services are a growing service area in the United States (Gysbers \& Henderson, 2012; Myrick, 2011; Piskin, 2006; Schmidt, 2008; Stephens, 1970; Yesilyaprak, 2019). When the distribution of the studies by countries was examined in general, it is concluded that G\&CP studies were conducted in countries in different geographies of the world.

When the G\&CP studies were examined in terms of the programme development process, it was concluded that the most focus was on the programme evaluation phase. Subjecting each programme to the evaluation process is regarded as an imperative for increasing the functionality of the programme (Guven, 2019). In addition, evaluation studies in comprehensive developmental guidance programmes are expressed as one of the most important stages of the programme development process (Nazli, 2005). For this reason, it can be believed that there is a relationship between the high number of programme evaluation studies in G\&CP research and the importance given to the programme evaluation process. In addition, it has been concluded that the studies involving all stages of the programme development process in G\&CP-related studies are quite high in number. In the studies carried out in this field, the holistic approach of the programme development process can be considered as an important factor that increases the impact of guidance and counselling services.

When the G\&CP studies were investigated according to development areas, besides the fact that social and emotional studies are much more; it was obvious that there were some studies in which social-emotional, academic and career development fields were addressed in a combined way. With the effect of social-emotional development on personality development (Erikson, 1959; Savarese et al., 2019), it is very important to improve intervention programmes in order to enhance such fields (Monica, 2019). Macdonald and Sink (1999) concluded as a result of the study, in which they conducted by taking provinces into account in America and analysed comprehensive developmental guidance models, that the biggest focus is on the social-emotional developmental 
field and the studies integrating the social-emotional, academic and career development fields are also high in number. Therefore, it can be said that findings of the study are consistent with the stated study. Additionally, it is obvious that the number of the studies addressing the career development is undeniably high in number. This result can be seen as a demonstration of the aim of imparting career skills (Cevik \& Senturk, 2019) to the individual with G\&CP, a fundamental assessment among 21 st-century skills. Supporting career development (Statnicke, Savaneviciene \& Sakys, 2019), which is generally regarded as one of the most important goals of life, and the implementation of programmes supporting career development are expressed as an important requirement today (Kaya, Anay, Abali, Karasu \& Girgin, 2017). In addition, according to Kuijpers and Meijers (2017) and Briddick and Sensoy-Briddick (2012), more importance has been attached to career development in Western societies in recent years. When evaluated from this point of view, it can be stated that there is a relationship between the importance given by Western societies to career development and the intensive study of G\&CP in this field.

Research on G\&CP has concluded that communitybased studies are higher than school-based studies. This result parallels with the change that guidance and counselling services have undergone in the historical development process. When the historical development of guidance and counselling services was examined, the target group was initially secondary students; later, as the students from all levels of school began to be considered, adult education, lifelong education, retirement preparation programmes, such as applications, were expanded to cover all age groups (Erkan, 2017). The services were provided only in schools at first, later new specialisations were established in different areas and with the help of that initiative, services for adults were started outside the school (Korkut-Owen, Sadri Damirchi \& Molaei, 2013; Tan, 1995). Today, guidance and counselling services offer services not only in school-based studies, but in many community-based areas, such as health, industry, outreach and sports (Koc, 2019). Counsellors operate in different fields, such as addiction, career, clinical mental health, marriage, couple and family counselling and communitybased counselling, and in a large workspace besides school counselling (American Counseling Association, 2019a; 2019b; Kucukkaragoz, 2020). In this study, it was concluded that consultation programmes related to the health field are being studied intensively within community-based G\&CP. Helwig and Schmidt (2011) expressed that research trends in guidance and psychological counselling have moved away from the roots of career development and school counselling and have begun to focus more on clinical issues. Within the scope of this research, rehabilitation counselling for patients and their relatives, maternal and child nutrition, prevention of substance, tobacco and alcohol addiction, studies on the prevention of infectious diseases, such as HIV, Ebola, etc., stand out. In community-based studies examined within the scope of this research, intervention programmes come to the fore compared to preventive programmes. It can be argued that there is a need for more intensive research on the preventive services which play an essential role in meeting the critical needs of children, adolescents and adults (Schmidt, 2008) and community-based preventive programmes (Akin-Little, Little \& Delligatti, 2004; Caplan, 1964; Durlak \& Wells, 1997; Korkut, 2003) in studies related to G\&CP.

It has been concluded that school-based studies on G\&CP are particularly focused on studying the effects of the programme. In school-based studies, studies examining the effects of school G\&CP on students' career development, academic achievement, social-emotional development and healthy living levels are prominent. These results of this research are consistent with the aims of school counselling. Because the goal of school counselling is to support lifecareer development through interventions to support the well-being of students (Yildiz \& Kilic, 2019; Villares \& Dimmitt, 2017) (Ellis, 1990; Gysbers; 1997; Gybers \& Henderson, 2012), it is possible to think that there is a relationship between the fact that there are too many studies examining the effects of the programme on students in schoolbased studies and the concept of accountability, which has a very important place in the G\&CP of schools. The need to demonstrate accountability through assessment research and to develop guidance practices is emerging as a major concern in school G\&CP (Lapan, Gysbers \& Sun, 1997). The concept of accountability (Erkan, 2017), which has great importance in all school G\&CP models today, which refers to proving the effectiveness of the programme with measurable data (American School Counsellor Association, 2019). The concept of accountability focuses on the student's academic achievement, social-emotional development and career development (Gysbers, 2001). In the literature, abundant is research available regarding the positive contribution of G\&CP to students' academic success, social-emotional and academic developments when it is used effectively (Carey \& Dimmit, 2012; Lapan, Gysbers \& Petrovski, 2001; Lapan, Gysbers \& Sun, 1997; Sink \& Stroh, 2003; Whiston, Tai, Rahardja \& Eder 2011). In addition, studies examining the effects of G\&CP on the prevention of violence and risky behaviour and prevention of school drop-out and absenteeism are also significantly highly involved in school-related studies. It can be understood that there can be relationship between the importance of prevention studies for children and adolescents in the educational process and the extensive number of research studies on study of school-based prevention studies in G\&CP-related research. Students in schools need some preventive basic interventions (Gybers \& Henderson, 2012). It is stated that interventions related to primary prevention should be based largely on school programmes (Abdi \& Sharyati, 2019). G\&CP is of great importance for the realisation of these interventions. The realisation of school-based orientation studies within a specific programme is seen as an important factor that increases the impact of these studies (Korkut, $2003 \mathrm{Uz}$ Bas, 2019). 
The research on G\&CP concluded that studies examining stakeholders' views on school-based counselling programmes were also extensively studied. The need to develop programmes that provide evidence-based services in school counselling is prominent (Erford, 2019). Stakeholders' views hold an important place as evidence of the effectiveness of the programme. There are many studies that examine the perceptions, views and experiences of school administrators, teachers, students and especially school counsellors regarding G\&CP. Stakeholders' views are a vital element in the design, delivery and evaluation of consultancy services (Astramovich \& Coker 2007). According to Gybers and Henderson (2012), school counsellors with guidance expertise are the most important stakeholders in the programme as the leader of change in the process of strengthening the programme. For this reason, studies on school-based G\&CP may be considered to involve studies on the perception, views and experiences of programme stakeholders (especially of school consultants).

There are studies within school-related studies addressing the evaluation of G\&CP and also designing models of them. These studies are more focusing on the ways of how the contents of G\&CP should be and how the models of G\&CP should be designed. Research on the implementation of the ASCA national model comes to the fore in studies related to G\&CP. The ASCA national model is expressed as a comprehensive model that aims to support students' socialemotional, academic, and career developments by increasing their success (American School Counselor Association, 2019). In addition, studies on how programmes should be evaluated and studies in which programme evaluation models are evaluated are available within school-related studies. The evaluation of G\&CP not only provides evidence for accountability but also contributes to the development and strengthening of the programme (Astramovich \& Coker 2007; Sherwood, 2010). In this respect, it can be stated that research on school-based programme evaluation studies is of great importance to the development of G\&CP.

It is observed that quantitative research methodology is mostly used in research related to G\&CP. This finding is similar to the results of research studies (Darmaji, Astalini, Kurniawan \& Perdana, 2019; Kettunen \& Tynjala, 2018), which stated that the vast majority of studies in the field of guidance and counselling still take place within the framework of the quantitative paradigm. In this respect, the low usage rate of mixed methods in G\&CP studies for schoolbased programme evaluation studies may be perceived as a negative situation. Because the combined use of qualitative and quantitative research provides clearer data on theory and practice (Heppner, Wampold \& Kivlighan, 2008), it also contributes to the increase in validity and reliability of research (Islek \& Asiksoy, 2019). Regarding the effectiveness of the mixed method, Davies (2000) states that combining qualitative and quantitative methods helps to explain various aspects of the subject being investigated by providing a more holistic understanding. Researches regarding the G\&CP show that experimental methods are mostly used. The wide usage of the experimental method within G\&CP, which is a special type of observation in which the observation conditions are prepared by the researcher artificially and exclusively for the purpose of examination, can be related to examining the effects of applied programmes. In addition, the findings reveal that the highest number of case study methods is used in qualitative and mixed method studies. Due to its advantages, such as establishing a harmonious dialogue between the specific and the universal (Mimoso, Bravo \& Gomes, 2018), conducting a comprehensive analysis of the current situation (Creswell, 2007) and ensuring a clear understanding of abstract theory and principles through unique examples in real situations (Cohen et al., 2007), the use of the case study in G\&CP can be considered positive. It is argued that using a qualitative approach based on deeper views of participants compared to quantitative methods in guidance and psychological counselling research, which can bring broader perspectives to cases, will significantly improve applications (Kettunen \& Tynjala, 2018). When evaluated from this point of view, it can be stated that the increase in qualitative and mixed approaches based on post-positivist paradigm is important in studies related to G\&CP.

Surveys and scales have been used most often as a data collection tool in G\&CP-related studies. The use of appropriate measurement tools for data collection in research is very important for the collection of qualified data (Ekici, 2012). Surveys and scales play an important role in social science research (Karagoz \& Ekici, 2004). A relationship can be established between the use of scale and surveys in the data collection process due to their ease of use, their applicability being greater (Cohen et al., 2007; Fraenkel, Wallen \& Hyun 2012) and reaching more participants in a shorter period of time (Hursen et al., 2016). It is also possible to think of a relationship between the frequent use of surveys and scales as a data collection tool and the excess of experimental studies. It was concluded that statistical analysis methods were used more intensively than qualitative data analysis methods in G\&CP studies. Descriptive statistics have often been used among statistical analysis methods. While it is considered important to show careful explanatory data in data analysis, it is often stated that inferential statistics provide more valuable and strong data (Cohen et al., 2007). When evaluated from this perspective, using inferential statistics in G\&CP studies can be considered as important. Methods of thematic analysis and descriptive analysis are often used in qualitative studies related to G\&CP, but phenomenological analysis, discourse analysis, ethnographic analysis and interaction analysis methods have also been used. The main objective of qualitative data analysis is to unearth the hidden information that lies in the depths of the social reality under study (Ozdemir, 2010). Studies on G\&CP may be expressed by qualitative data analysis methods where it is intended to reach generalisable expressions by comparing various situations, texts or materials (Flick, 2014). 
It is concluded that school consultants are the most preferred working group in G\&CP-related researches. It can be believed that there is a relationship between the intensive selection of school counsellors as the working group and the examination of the school counsellor's views regarding the programme evaluation process in the studies. However, it has been concluded that there are different levels of sample groups, such as school counsellors, students, patients, parents, school administrators, individuals with HIV virus, teachers, nursing mothers and smokers, in studies related to G\&CP. The high diversity of samples in studies can be considered as important in terms of G\&CP reaching a wider population.

The majority of the articles on G\&CP consist of articles with 5-9 authors. Studies show that there has been a tendency to publish jointly in the scientific world in recent years (Al, 2005). Multi-authored studies that enable interdisciplinary studies and help minimise the error rate by developing different perspectives are more preferred in G\&CP-related

\section{References}

Abdi, M. \& Sharyati, A. (2019). Comparing the training effects of problemsolving and coping skills with stress. Global Journal of Psychology Research: New Trends and Issues, 9(1), 16-22. doi:10.18844/gjpr.v9i1.4110

Ahmed, M., Djelti, S., \& Guellil, M. (2020). Migration, tourism, and the development of the home countries: Evidence from Morocco. Global Journal of Business, Economics and Management: Current Issues, 10(1), 44-57. doi.org/10.18844/gjbem.v10i1.4704

Akın-Little, K. A., Little, S. G. \& Delligatti, N. (2004). A preventative model of school consultation: Incorporating perspectives from positive psychology. Psychology in the Schools, 41(1), 155-162. doi:10.1002/pits.10147

Al, U. (2005). Cok yazarliligin bilimsel iletisimdeki yeri (The place of multiauthorship in scientific communication). In M. E. Kucuk (Ed.), Prof. Dr. Nilufer Tuncer'e armaganicinde (pp. 31-41). Ankara, Turkey: TKD. Retrieved October $10, \quad 2014, \quad$ from http://yunus.hacettepe.edu.tr/ umutal/publications /multipleauthorship.pdf

American Counseling Association (2019a). About ACA. What is counseling? Retrieved November 1, 2019, from https://www.counseling.org/

American Counseling Association (2019b). Choosing a career in counseling. Retrieved October 10, 2019, from https://www.counseling.org/

American School Counselor Association (2019). ASCA national model a framework, for school counseling programs. Retrieved October 12, 2019, from https://schoolcounselor.org/

Astramovich, R. L. \& Coker, J. K. (2007). Program evaluation: the accountability bridge model for counselors. Journal of Counseling and Development, 85(2). doi:10.1002/j.1556-6678.2007.tb00459.x

Briddick, W. C. \& Sensoy-Briddick, H. (2012). The concept of role models in life design. Cypriot Journal of Educational Sciences, 7(4), 326-333. Retrieved March 5, 2014, from http://awer-center.org/cjes/

Buboltz, W. C. Jr., Miller, M. \& Williams, D. J. (1999). Content analysis of research in the Journal of Counseling Psychology (1973-1998). Journal of Counseling Psychology, 46(4), 496-504. Retrieved November 5, 2019, from http://eds.a.ebscohost.com.ezproxy.neu.edu.tr/

Buboltz, W., Jr., Deemer, E. \& Hoffmann, R. (2010). Content analysis of the Journal of Counseling Psychology: Buboltz, Miller, and Williams (1999) 11 years later. Journal of Counseling Psychology, 57(3), 368-375. doi: $10.1037 / \mathrm{a} 0020028$

Büyüköztürk, Ş., Kılıç Çakmak, E., Akgün, Ö.E., Karadeniz, Ş. \& Demirel, F. (2012). Bilimsel araştırma yöntemleri (13. Ed.). Ankara: Pegem Akademi Yayınları.

Calik, M. \& Sozbilir, M. (2014). Parameters of content analysis. Education and Science, 39(174), 33-38. doi:10.15390/EB.2014.3412 articles. This can be considered as an indication of the importance that researchers place on collaboration in G\&CP studies.

The results obtained from this study, which was conducted to determine research trends related to G\&CP, are thought to contribute to new studies and applications that will be made to the researchers. In line with the findings from this study, G\&CP-related research, the dissemination of qualitative research methodologies in mixed research and greater use of different data collection tools and data analysis methods, a combination of research organised in a way that would cover all of the curriculum development processes, community-based preventive programmes and intervention programmes in studies in conjunction with intensive study of school-based programme models in studies about the application studies may be recommended. It can also be said that it would be beneficial to repeat the studies; which might be beneficial to identify the current trend of G\&CP periodically in upcoming years.

Caplan, G. (1964) Principles of preventive psychiatry. New York: Basic Books.

Carey, J. \& Dimmit, C. (2012). School counseling and student outcomes: summary of six statewide studies. Professional School Counseling, 16(21), 146-153. doi:10.1177/2156759X0001600204.

Cevik, M. \& Senturk C. (2019). Multidimensional 21st century skills scale: validity and reliability study. Cypriot Journal of Educational Sciences, 14(1), 011-028. doi:10.18844/cjes.v14i1.3506

Chadegani, A. A., Salehi, H., Yunus, M. M., Farhadi, H., Fooladi, M., Farhadi, M. \& Ebrahim, N. A. (2013). A comparison between two main academic literature collections: web of Science and Scopus databases. Asian Social Science, 9(5), 18-26. doi:10.5539/ass.v9n5p18

Cohen, L., Manion, L. \& Morrison, K. (2007). Research methods in education (5th ed.). London and New York: Routledge Falmer.

Council for Accreditation of Counseling and Counseling Related Programs (2016). CACREP Standards. Retrieved November 4, 2019, from http://www.cacrep.org/

Creswell, J. W. (2007). Qualitative inquiry and research design: choosing among five approaches. Thousand Oaks, CA: Sage Publications

Darmaji, D., Astalini, A., Kurniawan, D. \& Perdana, R. (2019). A study relationship attitude toward physics, motivation, and character discipline students senior high school, in Indonesia. International Journal of Learning and Teaching, 11(3), 99-109. doi:10.18844/ijlt.v11i3.4207

Davies, P. (2000). Contributions from qualitative research. In H. T. Davies, M. N. Sandra \& P. Smith (Eds.), What works? Evidence-based policy and practice in public services (pp. 291-316). Bristol, UK: Policy Press.

Dincer, S. (2018). Content analysis in for educational science research: metaanalysis, meta-synthesis, and descriptive content analysis. Bartin University Journal of Faculty of Education, 7(1), 176-190. doi:10.14686/buefad.363159

Donald, E. \& Ng, K. M. (2014). A critical review of content-analytic papers in ACA- and APA-sponsored journals from 1980-2011. International Journal for the Advancement of Counselling, 36(1), 136 doi:10.1007/s10447-013-9186-8

Durlak, J. A. \& Wells, A. M. (1997). Primary prevention mental health programs for children and adolescents: a meta-analytic review. American Journal of Community Psychology, 25(2). doi:10.1023/A:1024654026646

Ekici, G. (2012). Akademik oz -yeterlilik olcegi: Turkceye uyarlama geçerlilik ve guvenirlilik calisması (Academic self-sufficiency scale: Turkish adaptation validity and reliability study). Hacettepe Universitesi Egitim Fakultesi Dergisi, 43, 174-185. Retrieved December 15, 2013, from http://www.efdergi.hacettepe.edu.tr 
Ellis, T. I. (1990). The Missouri comprehensive guidance model. Highlights: an ERIC/CAPS digest. ERIC Clearinghouse on Counseling and Personnel Services Ann Arbor MI. Retrieved October 15, 2019, from https://www.ericdigests.org/pre-9214/missouri.htm

Erford, B. T. (2019) Transforming the school counseling profession (5th ed.). Upper Saddle River, NJ: Pearson Education, Inc. Retrieved October 5, 2019, from https://www.pearsonhighered.com/

Erikson, E. H. (1959). Identity and the life cycle: selected papers. Oxford, UK: International Universities Press.

Erkan, S. (2017). Psikolojik danisma ve rebberlikte program gelistirme (Program development in counseling and guidance). Ankara, Turkey: Pegem Yay.

Falco, L. D., Bauman, S., Sumnicht, Z. \& Engelstad, A. (2011). Content analysis of the "Professional School Counseling Journal: the first ten years. Professional School Counseling, 14(4), 271-277. Retrieved October 15, 2019, from https://www.jstor.org/

Feeney, M. (2014). Understanding news researchers through a content analysis of dissertations and theses. Qualitative and Quantitative Methods in Libraries (QQML), 1, 263-270. Retrieved October 5, 2019, from http://www.qqml-journal.net

Flick, U. (2014). Mapping the field. In U. Flick (Ed.), The SAGE bandbook of qualitative data analysis. Thousand Oaks, CA: SAGE Publications Inc. Retrieved October 22, 2019, from https://books.google.com.tr/

Fraenkel, J. R., Wallen, N. E. \& Hyun, H. H. (2012). How to design and evaluate research in education (8th ed.). New York: Mc Graw Hill.

Garbin, M., Trombeta de Oliveira, E., Pirillo, N., \& Telles, S. (2020). Pedagogical practices based on areas of knowledge: Reflections on the technology use. New Trends and Issues Proceedings on Humanities and Social Sciences, 7(1), 134-141. doi.10.18844/prosoc.v7i1.4877

Guven, S. (2019). Okul psikolojik danisma ve rehberlik programlarının geliştirilmesi [Development of school counseling and guidance programs]. In M. Guven (Ed.). Psikolojik Danisma ve Rehberlik (11th ed., pp. 274-299). Ankara, Turkey: Ani Yay.

Gysbers, N. C. (2001). School guidance and counseling in the 21st century: Remember the past into the future. Professional School Counseling, 5(2), 96-105. Retrieved November 15, 2019, from https://www-jstororg.ezproxy.neu.edu.tr/

Gysbers, N.C. (1997). A model comprehensive guidance program. In N. Gysbers \& P. Henderson (Eds.), Comprehensive guidance programs that workII, Chapter 1 (pp. 49-61). ERIC Counselling and Student Services Cleraring house. Retrieved December 15, 2018, from https://eric.ed.gov/?id=ED412434

Gysbers, N. C. \& Henderson, P. (2012). Developing \& managing your school guidance program. (5th ed.). Alexandria, VA: American Counseling Association.

Helwig, A. A. \& Schmidt, L. L. (2011). Content analysis of 32 years of American Counseling Association Convention Programs. Journal of Counseling \& Development, 89(2), 148-154. doi:10.1002/j.15566678.2011.tb00072.x

Heppner, P. P., Kivlighan, D. M. \& Wampold, B. E. (2008). Research design in counseling. (3th ed.). Belmont, CA: Thomson Higher Education.

Hursen, C., Koruoglu, A., Bahali, S. \& Mercan, N. (2016). Determining new trends with regard to the studies in curricula and instruction field. Cypriot Journal of Educational Science, 11(2), 77-91. doi:10.18844/cjes.v11i2.900

Ilgar, M. Z. (2002) Rehberligin baslica turleri [Major types of guidance]. In Gurhan CAN (Ed.), Psikolojik Danisma ve Rebberlik (2nd ed., pp. 26-41). Ankara, Turkey: Pegem Yayincilik.

Illovsky, M. E. (2013). Foundations of counselling people: a guide for the counseling, psychological, and helping professions. Springfield, IL: Charles C. Thomas Publisher. Retrieved November 1, 2019, from http://eds.a.ebscohost.com.ezproxy.neu.edu.tr/

Islek, D. \& Asiksoy, G. (2019). The studies conducted regarding virtual museum area: a content analysis research. World Journal on Educational Technology: Current Issues, 11(1), 87-93. doi:10.18844/wjet.v11i1.4012

Kaptan, S. (1998). Bilimsel arastırmalar ve istatistik teknikleri (11 th ed.). Ankara, Turkey: Gazi Yayinevi.

Karagoz, Y. \& Ekici, S. (2004). Sosyal bilimlerde yapilan uygulamali arastirmalarda kullanilan istatistiksel teknikler ve olcekler [Statistical techniques and scales used in Applied Research in Social Sciences].
Cumburiyet Universitesi Iktisadi ve Idari Bilimler Fakultesi Dergisi, 5(1), 25 43. Retrieved January 5, 2014, from http://www.ebscho.com

Karasar, N. (2005). Bilimsel araştırma yontemi (15th ed.). Ankara, Turkey: Nobel Yay.

Karasozen, B., Bayram, O. \& Zan B. U. (2011). Comparison of the WOS and Scopus Database. Turk Kutuphaneciligi, 25(2), 238-260.

Kaya, Z., Anay, M. O., Abali, G., Karasu, G. \& Girgin, M.C. (2017). Acquaintance with profession: using internship as a tool for hearingimpaired university students. Contemporary Educational Researches Journal, 7(3), 134-143. doi: 10.18844/cerj.v7i3.2649

Kettunen, J. \& Tynjala, P. (2018). Applying phenomenography in guidance and counselling research, British Journal of Guidance \& Counselling, 46(1), 1-11. doi:10.1080/03069885.2017.1285006

King, W. R. \& He, J. (2005). Understanding the role and methods of metaanalysis in IS research. Communications of the Association for Information Systems, 16(32), 665-686. doi:10.17705/1CAIS.01632

Koc, M. (2019). Psikolojik danisma ve rehberlikte baslica hizmet turleri [Main types of services in counseling and guidance]. In M. Guven (Ed.), Psikolojik Danisma ve Rebberlike (11th ed., pp. 46-63). Ankara, Turkey: Ani Yayincilik.

Korkut, F. (2003). Prevention services in guidance. Selcuk Universitesi Sosyal Bilimler Enstitusu Dergisi, 9, 441-452. Retrieved November 5, 2019, from http://dergisosyalbil.selcuk.edu.tr/

Korkut-Owen, F., Sadri Damırchi, E. \& Molaei, B. (2013). Iki Orta Dogu Ulkesinde psikolojik danisma ve rehberlik alani: Turkiye ve Iran [Psychological counseling and guidance in two Middle Eastern countries: Turkey and Iran]. Uludag Universitesi Egitim Fakultesi Dergisi, 26(1), 81103. Retrieved November 18, 2019, from https://dergipark.org.tr/en/download/article-file/153494

Kousha, K. \& Thelwall, M. (2019). Can Google Scholar and Mendeley help to assess the scholarly impacts of dissertations? Journal of Informetrics, 13(2), 467-484. doi:10.1016/j.joi.2019.02.009

Kucukkaragoz, H. (2020). Family environment and emotional quotient in primary school 3rd grade students. Cypriot Journal of Educational Sciences, 15(2), 336-348. doi:10.18844/cjes.v15i2.4805

Kuijpers, M. \& Meijers, F. (2017). Professionalising teachers in career dialogue: an effect study. British Journal of Guidance \& Counselling, 45(1), 8396.

Kuzgun, Y. (2009) Rehberlik ve psikolojik danışma [Guidance and psychological counselling7 (10th ed.). Ankara, Turkey: Nobel Yayinlari.

Lapan, R. T., Gysbers, N. C., Petroski, G. F. (2001). Helping seventh graders be safe and successful: A statewide study of the impact of comprehensive guidance and counseling programs. Journal of Counseling \& Development, 79(3), 320-330. Retrieved November 10, 2019, from http://eds.a.ebscohost.com.ezproxy.neu.edu.tr/

Lapan, R. T., Gysbers, N. C. \& Sun, Y. (1997). The impact of more fully implemented guidance programs on the school experiences of high school students: a statewide evaluation study. Journal of Counseling and Development, 75, 292-302. Retrieved November 10, 2019, from http://eds.b.ebscohost.com.ezproxy.neu.edu.tr/

Liu, W. (2019). The data source of this study is Web of Science Core Collection? Not enough. Scientometrics, 1-10. doi:10.1007/s11192-019-03238-1

Lombard, M., Snyder-Dutch, J. \& Bracken, C. C. (2004). A call for standardization in content analysis reliability. Human Communication Research, 30(3), 434-437. doi::10.1111/j.1468-2958.2004.tb00739.x

Macdonald, G. \& Sink, C.A. (1999). A qualitative developmental analysis of comprehensive guidance programmes in schools in the United States. British Journal of Guidance and Counselling, 27(3), 415-430. doi:10.1080/03069889908256281

Miles, M, B. \& Huberman, A. M. (2016). Qualitative data analysis: an expanded Sourcebook. SSadegul Akbaba Altun, Ali Ersoy Cev.] (2nd ed.). Ankara, Turkey: Pegem Akademi Yay.

Miller, F. W., Fruehling, J. A. \& Lewis, G. J. (1978). Guidance principles and services. (3rd. ed.). Columbus, $\mathrm{OH}$ : Charles E. Merrill Books.

Mimoso, M. J., Bravo, B. M. \& Gomes, J. C. (2018). The case study in learning law. Global Journal of Sociology: Current Issues, 8(2), 60-65. doi:10.18844/gis.v8i2.3519

Monica, C. (2019). The intervention: improving social-emotional skills in early childhood as a factor of school performance. New Trends and Issues 
Proceedings on Humanities and Social Sciences, 6(1), 344-354. doi:10.18844/prosoc.v6i1.4187

Morichika, N. \& Shibayama, S. (2016). Use of dissertation data in science policy research. Scientometrics, 108, 221-241. doi:10.1007/s11192-0161962-x

Myrick, R. D. (2011). Developmental guidance and counseling: a practical approach. (50th ed.). Minneapolis, MN: Educational Media Corporation. Retrieved November 10, 2019, from https://www.academia.edu

Nazli, S. (2005). Kapsamli gelisimsel rebberlike ve psikolojik danisma programlari Comprehensive developmental guidance and counseling programs]. Ankara, Turkey. Ani Yay.

Oh, J., Stewart, A. E. \& Phelps, R. E. (2017). Topics in the Journal of Counseling Psychology, 1963-2015. Journal of Counseling Psychology, 64(6), 604-615. doi:10.1037/cou0000218

Ozcinar, Z. (2020). Development of teacher-parent communication competence scale (TPCCS). Cypriot Journal of Educational Sciences, 15(2), 349357. doi.10.18844/cjes.v15i2.4806

Ozdemir, M. (2010). Nitel veri analizi: Sosyal bilimlerde yontembilim sorunsali uzerine bir calisma [Qualitative data analysis: a study on the problem of methodology in the Social Sciences]. Eskisehir Osmangazi Universitesi Sosyal Bilimler Dergisi, 11(1), 323-343. Retrieved November 12, 2019, from http://www.ebscho.com

Park, K. (2020). Trend of income inequality in Asia and effects of education. Contemporary Educational Researches Journal, 10(2), 42-59. doi. 10.18844/cerj.v10i2.4681

Piskin, M. (2006). Turkiye'de Psikolojik Danisma ve Rehberlik Hizmetlerinin Dunu, Bugunu ve Yarını. In M. Hesapcioglu \& A. Durmus (Eds.), Turkiye'de egitim bilimleri: Bir bilanco denemesi (The past, present and tomorron of psychological counseling and guidance services in Turkey. Educational: a balance sheet experiment sciences in Turkey (1st ed., pp. 457-501). Ankara, Turkey: Nobel Akademik Yayincilik.

Saricam, H., \& Ozbey, A. (2019). School anxiety and presenteeism in refugee children in Turkey. Global Journal of Guidance and Counseling in Schools: Current Perspectives, 9(2), 67-79. doi.10.18844/gigc.v9i2.4427

Savarese, G., Pecoraro, N., Fasano, O., Mollo, M., Iannaccone, A., Manzi, F. \& Curcio, L. (2019). Perceived social support and clinical symptomatology in Italian university students. Global Journal of Guidance and Counseling in Schools: Current Perspectives, 9(3), 90-94. doi:10.18844/gigc.v9i3.4121

Schmidt, J. J. (2008). Counseling in schools: comprehensive programs of responsive services for all students (5th ed.). Upper Saddle River, NJ: Pearson Publisher.

Shertzer, B. \& Stone, S. C. (1981). Fundamentals of guidance (4th ed.). Boston, MA: Houghton Mifflin.

Sherwood, H. (2010). A school counseling program evaluation: Utilizing staff perceptions to guide and shape future program planning. Georgia School Counselors Association Journal, 17(1), 15-25. Retrieved November 12, 2013, from https://eric.ed.gov/?id=EJ909074

Sink, C.A. \& Stroh, H. R. (2003). Raising elementary test scores of early elementary school students through comprehensive school counseling programs. Professional School Counseling, 6(5), 350-364.

Statnicke, G., Savaneviciene, A. \& Sakys, I. (2019). Career engagement of different generations: a case study in the information and communication technology (ICT) sector in Lithuania. New Trends and Issues Proceedings on Humanities and Social Sciences, 6(2), 37-49. doi:10.18844/prosoc.v6i3.4334

Stephens, W. R. (1970). Social reform and the origins of vocational guidance. Washington, DC: National Vocational Guidance Association.
Stosic, L., Dermendzhieva, S., \& Tomczyk, L. (2020). Information and communication technologies as a source of education. World Journal on Educational Technology: Current Issues, 12(2), 128-135. doi.org/10.18844/wjet.v12i2.4815

Strauss, A. \& Corbin, J. M. (1990). Basics of qualitative research: grounded theor procedures and techniques. Thousand Oaks, CA: Sage Publications, Inc.

Tan, H. (1995) Psikolojik damsma ve rebberlik. (Psychological counseling and guidance). Ankara, Turkey: MEB Yayinlari.

Thompson, R. (1992). School counseling renewal: strategies for the twenty-first century. Muncie, IN: Accelerated Development Inc.

Turk, F. \& Cihangiroglu, U. (2018). Thematic and methodological investigation of applied postgraduate theses on psychological counseling and guidance. International Journal of Eurasia Social Sciences, 9(31), 276-311. Retrieved November 10, 2019, from http://www.ijoess.com/

Uz Bas, A. (2019). School-based prevention: characteristics of effective school-based prevention programs. Journal of School Psychological Counseling, 2(1), 73-94. Retrieved November 17, 2019, from https://dergipark.org.tr/

Uzunboylu, H. \& Gundogdu, E. E. (2018). Okul Oncesi Egitim ve Ogretim Teknolojileri Ile Ilgili Yapılan Arastirmalarla Ilgili Bir Icerik Analizi Calismasi [A content analysis study related to research related to preschool education and instructional technologies]. International Journal of Innovative Research in Education, 5(4), 119-128. doi:10.18844/ijire.v5i4.3974

Uzunboylu \& Altay. (2019) State of affairs in multicultural education research: a content analysis, Compare: A Journal of Comparative and International Education, DOI: 10.1080/03057925.2019.1622408

Vasiliene-Vasiliauskiene, V., Vasilis Vasiliauskas, A., MeiduteKavaliauskiene, I. \& Sabaityte, J. (2020). Peculiarities of educational challenges implementing project-based learning. World Journal on Educational Technology: Current Issues, $12(2), \quad$ 136-149. doi:10.18844/wjet.v12i2.4816

Villares, E. \& Dimmitt, C. (2017). Updating the school counseling research agenda: a Delphi study. Counselor Education \& Supervision, 56, 177192. doi:10.1002/ceas.12071

Whiston, S. C. (2007). Outcome research on school counseling interventions and programs. In B. T. Erford (Ed.), Professional school counseling on the cutting edge (2nd ed., pp. 38-50). Upper Saddle River, NJ: Prentice Hall

Whiston, S. C., Tai, W. L., Rahardja, D. \& Eder, K. C. (2011). School counseling outcome: a meta-analytic examination of interventions. Journal of Counseling \& Development, 89, 37-55. Retrieved October 18, 2019, from http://eds.a.ebscohost.com.ezproxy.neu.edu.tr/

Yesilyaprak, B. (2019) 21. Yusvilda egitimde rebberlik birmetleri-gelisimsel yaklasim [21. Guidance services in education in the century-developmental approach] (28th ed.). Ankara, Turkey: Nobel Yay.

Yildırım, A. \& Simsek, H. (2006). Sosyal bilimlerde nitel arasturma yontemleri (5th ed.). Ankara, Turkey: Seckin Yay.

Yildiz, V. \& Kilic, D. (2019). Examining the motivations of primary school fourth grade students with regard to homework. Contemporary Educational Researches Journal, 9(4), 110-118. doi:10.18844/cerj.v9i4.4439

Zagelbaum, A., Kruczek, T., Alexander, C. \& Crethar, H. (2014). Where are we now? An updated review of the school counseling literature for trends and themes. Journal of School Counseling, 12(4), 1-25. Retrieved November 10, 2019, from https://files.eric.ed.gov/

Zaid, M. (2020). Code-switching: The case of "Israeli Arab" students at the Arab American University-Palestine. Global Journal of Foreign Language Teacbing, 10(1), 20-31. https://doi.org/10.18844/gjflt.v10i1.4409 